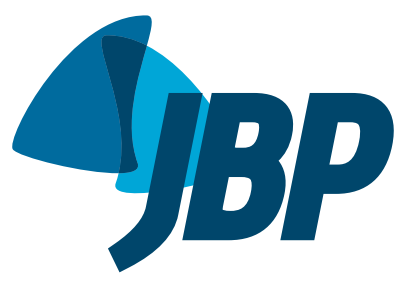

\title{
The challenge of managing extensively drug-resistant tuberculosis at a referral hospital in the state of São Paulo, Brazil: a report of three cases
}

\author{
Marcos Abdo Arbex ${ }^{1,2}$, Hélio Ribeiro de Siqueira ${ }^{3,4}$, Lia D’Ambrosio ${ }^{5,6}$, \\ Giovanni Battista Migliori ${ }^{5}$
}

1. Hospital Nestor Goulart Reis, Secretaria de Estado da Saúde do Estado de São Paulo, Américo Brasiliense (SP) Brasil.

2. Curso de Medicina, Centro Universitário de Araraquara, Araraquara (SP) Brasil.

3. Disciplina de Pneumologia e Tisiologia, Faculdade de Ciências Médicas, Universidade do Estado do Rio de Janeiro, Rio de Janeiro (RJ) Brasil.

4. Ambulatório de Tuberculose, Hospital Universitário Pedro Ernesto, Universidade do Estado do Rio de Janeiro, Rio de Janeiro (RJ) Brasi

5. WHO Collaborating Centre for TB and Lung Diseases, Istituto Scientifico, Fondazione Salvatore Maugeri, Tradate, Italia.

6. Public Health Consulting Group, Lugano, Switzerland.

Submitted: 17 September 2015. Accepted: 18 November 2015

\begin{abstract}
Here, we report the cases of three patients diagnosed with extensively drug-resistant tuberculosis and admitted to a referral hospital in the state of São Paulo, Brazil, showing the clinical and radiological evolution, as well as laboratory test results, over a oneyear period. Treatment was based on the World Health Organization guidelines, with the inclusion of a new proposal for the use of a combination of antituberculosis drugs (imipenem and linezolid). In the cases studied, we show the challenge of creating an acceptable, effective treatment regimen including drugs that are more toxic, are more expensive, and are administered for longer periods. We also show that treatment costs are significantly higher for such patients, which could have an impact on health care systems, even after hospital discharge. We highlight the fact that in extreme cases, such as those reported here, hospitalization at a referral center seems to be the most effective strategy for providing appropriate treatment and increasing the chance of cure. In conclusion, health professionals and governments must make every effort to prevent cases of multidrug-resistant and extensively drug-resistant tuberculosis.
\end{abstract}

Keywords: Tuberculosis, multidrug-resistant; Extensively drug-resistant tuberculosis; Antitubercular agents; Antibiotics, antitubercular.

Study carried out at Hospital Nestor Goulart Reis, Secretaria de Estado da Saúde do Estado de São Paulo, Américo Brasiliense (SP) Brasil.

\section{INTRODUCTION}

The number of cases of multidrug-resistant tuberculosis (MDR-TB) and extensively drug-resistant tuberculosis (XDR-TB) has increased significantly, MDR-TB and XDR-TB having become a serious public health problem worldwide. Recent data show that the number of cases of MDR-TB tripled between 2009 and 2013. ${ }^{(1)}$ In 2013, cases of MDR-TB accounted for $3.5 \%$ of all new tuberculosis cases and $20.5 \%$ of all previously treated tuberculosis cases. Cases of XDR-TB accounted for $9 \%$ of all MDR-TB cases reported in 100 countries. ${ }^{(1)}$ MDR-TB is caused by Mycobacterium tuberculosis strains that are resistant to rifampin and isoniazid, whereas XDR-TB is caused by strains that are also resistant to any fluoroquinolone and at least one of three injectable second-line drugs (amikacin, kanamycin, and capreomycin).(1-3) The increasing recognition of MDR-TB and XDR-TB has led to the development of new therapeutic strategies combining standard and new antituberculosis drugs. The World Health Organization (WHO) has divided first-line drugs (which are more effective), second-line drugs (which are less effective, are more toxic, and require longer treatment duration), and additional drugs for reinforcement (the use of which depends on their efficacy and tolerability) into five groups. ${ }^{(1,4,5)}$ Table 1 shows the five groups of drugs and the WHO recommendations for their use.

A standard or an individualized approach can be used in order to treat patients with MDR-TB. Official agencies recommend standard treatment regimens on the basis of health data (e.g., resistance patterns) in a given region. ${ }^{(2,3,6)}$ In Brazil, the treatment of MDR-TB is standardized by the National Ministry of Health. ${ }^{(7)}$ The $\mathrm{WHO}^{(1)}$ recommends that the treatment of MDR-TB be divided into two phases: the intensive phase and the maintenance phase. In the intensive phase, which lasts 8 months, at least four potentially effective drugs should be used: an injectable drug (group 2), a fluoroquinolone (group 3), an oral drug (group 4), and an additional drug for reinforcement (group 5). In the maintenance phase, the injectable drug is discontinued, and the remaining drugs should be continued for 12 months after a negative sputum culture. . $^{(1,8,9)}$ However, according to some authors, MDR-TB treatment should continue for at least 20 months. Recent studies have shown that continuing treatment for 18 months after a negative sputum culture prevents treatment failure, recurrence, and mortality. ${ }^{(8-11)}$ 
Table 1. Antituberculosis drug groups proposed by the World Health Organization and step-by-step recommendations for creating a treatment regimen for patients with multidrug-resistant or extensively drug-resistant tuberculosis.

\begin{tabular}{|c|c|c|c|c|c|}
\hline Groups & Drugs & Steps & What to do & Drugs to consider & Notes \\
\hline 1 & $\begin{array}{l}\text { First-line oral drugs } \\
\text { - Isoniazid } \\
\text { - Rifampin } \\
\text { - Ethambutol } \\
\text { - Pyrazinamide } \\
\text { - Rifabutin } \\
\text { - Rifapentine } \\
\end{array}$ & 1 & $\begin{array}{l}\text { Choose an } \\
\text { injectable (group 2) } \\
\text { drug on the basis of } \\
\text { drug susceptibility } \\
\text { test results or } \\
\text { patient history } \\
\text { of tuberculosis } \\
\text { treatment. }\end{array}$ & $\begin{array}{l}\text { amikacin, } \\
\text { capreomycin, and } \\
\text { kanamycin }\end{array}$ & $\begin{array}{l}\text { Streptomycin is } \\
\text { not generally used, } \\
\text { because MDR-TB is } \\
\text { highly resistant to it. }\end{array}$ \\
\hline 2 & $\begin{array}{l}\text { Injectable drugs } \\
\text { - Streptomycin } \\
\text { - Kanamycin } \\
\text { - Amikacin } \\
\text { - Capreomycin }\end{array}$ & 2 & $\begin{array}{l}\text { Choose a next- } \\
\text { generation } \\
\text { fluoroquinolone } \\
\text { (group 3). }\end{array}$ & $\begin{array}{l}\text { levofloxacin and } \\
\text { moxifloxacin }\end{array}$ & $\begin{array}{l}\text { In case of resistance } \\
\text { to levofloxacin, } \\
\text { moxifloxacin should } \\
\text { be used. Moxifloxacin } \\
\text { should be avoided in } \\
\text { case bedaquiline is } \\
\text { used. }\end{array}$ \\
\hline 3 & $\begin{array}{l}\text { Fluoroquinolones } \\
\text { - Levofloxacin } \\
\text { - Moxifloxacin } \\
\text { - Gatifloxacin }\end{array}$ & 3 & $\begin{array}{l}\text { Add two or more } \\
\text { group } 4 \text { drugs. }\end{array}$ & $\begin{array}{l}\text { cycloserine, } \\
\text { terizidone, para- } \\
\text { aminosalicylic acid, } \\
\text { ethionamide, and } \\
\text { prothionamide }\end{array}$ & $\begin{array}{l}\text { Ethionamide and } \\
\text { prothionamide are the } \\
\text { most effective group } 4 \\
\text { drugs. Patient history of } \\
\text { tuberculosis treatment, } \\
\text { side effects, and } \\
\text { cost should be taken } \\
\text { into consideration. } \\
\text { In general, drug } \\
\text { susceptibility testing } \\
\text { does not include group } \\
3 \text { drugs. }\end{array}$ \\
\hline 4 & $\begin{array}{l}\text { Oral second-line drugs } \\
\text { - Ethionamide } \\
\text { - Prothionamide } \\
\text { - Cycloserine } \\
\text { - Terizidone } \\
\text { - Para-aminosalicylic acid } \\
\text { - Sodium aminosalicylate }\end{array}$ & 4 & Add group 1 drugs. & $\begin{array}{l}\text { pyrazinamide and } \\
\text { ethambutol }\end{array}$ & $\begin{array}{l}\text { Pyrazinamide is } \\
\text { commonly used in } \\
\text { most treatment } \\
\text { regimens. Ethambutol } \\
\text { is used on the basis } \\
\text { of susceptibility test } \\
\text { results. }\end{array}$ \\
\hline 5 & $\begin{array}{l}\text { Additional drugs for } \\
\text { reinforcement } \\
\text { - Linezolid } \\
\text { - Ertapenem } \\
\text { - Imipenem/cilastatin } \\
\text { - Meropenem } \\
\text { - Clarithromycin } \\
\text { - Thiacetazone } \\
\text { - Amoxicillin/clavulanate } \\
\text { - Clofazimine } \\
\text { - High-dose isoniazid (has a } \\
\text { modest effect) } \\
\text { - Bedaquiline } \\
\text { - Delamanid }\end{array}$ & 5 & $\begin{array}{l}\text { Consider the } \\
\text { possibility of adding } \\
\text { group } 5 \text { drugs in } \\
\text { case it is impossible } \\
\text { to use } 4 \text { effective } \\
\text { group 2-3-4 drugs. }\end{array}$ & $\begin{array}{l}\text { bedaquiline, } \\
\text { linezolid, } \\
\text { clofazimine, } \\
\text { amoxicillin/ } \\
\text { clavulanate, } \\
\text { ertapenem, } \\
\text { imipenem/cilastatin } \\
\text { + clavulanate, } \\
\text { meropenem + } \\
\text { clavulanate, high- } \\
\text { dose isoniazid, } \\
\text { clarithromycin, and } \\
\text { thiacetazone }\end{array}$ & $\begin{array}{l}\text { If necessary, } 2 \text { or } \\
\text { more group } 5 \text { drugs } \\
\text { can be used. It should } \\
\text { be noted that there } \\
\text { are no standardized } \\
\text { susceptibility tests for } \\
\text { group } 5 \text { drugs. }\end{array}$ \\
\hline
\end{tabular}

Adapted from the World Health Organization(1) and Zumla et al.(8) MDR-TB: multidrug-resistant tuberculosis.

The treatment of XDR-TB should be individualized on the basis of patient history of tuberculosis treatment and patterns of resistance to first- and second-line drugs. ${ }^{(1,6,8)}$ For patients with XDR-TB, the $\mathrm{WHO}^{(1)}$ recommends special precautions: the use of pyrazinamide and/ or another group 1 drug; the use of next-generation quinolones (moxifloxacin or gatifloxacin) even if drug susceptibility test results show resistance to levofloxacin, ofloxacin, or both; whenever possible, the use of the injectable antituberculosis agent (aminoglycoside or capreomycin) to which the bacterial sample is susceptible, which should continue for 12 months or even for the duration of the treatment; the use of two or more group 5 drugs; and the use of all group 4 drugs that have not been extensively prescribed or that are considered effective.

The objective of the present study was to show the 1-year progression of three XDR-TB patients admitted to Hospital Nestor Goulart Reis (HNGR), which is located in the city of Américo Brasiliense, Brazil, and is a São 
The challenge of managing extensively drug-resistant tuberculosis at a referral

hospital in the state of São Paulo, Brazil: a report of three cases

Paulo State Department of Health referral hospital for the treatment of MDR-TB and XDR-TB patients requiring hospitalization.

\section{CASE REPORTS}

Below, we describe the cases of three patients who were admitted to and treated at our institution.

Table 2. Treatment setting, duration, regimen, and outcome, as well as drug susceptibility test results, for the three patients in the present study prior to their admission to Hospital Nestor Goulart Reis, located in the city of Américo Brasiliense, Brazil.

\begin{tabular}{|c|c|c|c|c|c|c|c|c|c|c|c|c|c|c|}
\hline \multirow{2}{*}{$\begin{array}{l}\text { Treatment } \\
\text { setting }\end{array}$} & \multirow{2}{*}{$\begin{array}{l}\text { Drug susceptibility } \\
\text { testing }\end{array}$} & \multirow{2}{*}{$\begin{array}{l}\text { Treatment } \\
\text { duration (from } \\
\text { month/year to } \\
\text { month/year) }\end{array}$} & \multicolumn{11}{|c|}{ Treatment regimen } & \multirow{2}{*}{$\begin{array}{l}\text { Treatment } \\
\text { outcome }\end{array}$} \\
\hline & & & $\mathbf{R}$ & H & $\mathbf{Z}$ & E & $\mathbf{S}$ & Et & 0 & $\mathbf{T}$ & C & A & L & \\
\hline \multicolumn{15}{|l|}{ Patient 1} \\
\hline Outpatient & $\begin{array}{l}\text { Resistance to } \\
(\mathrm{R}, \mathrm{H}, \mathrm{E}, \mathrm{S})\end{array}$ & 05/2001-11/2001 & $x$ & $x$ & $x$ & & & & & & & & & Failure \\
\hline Outpatient & $\begin{array}{l}\text { Resistance to } \\
(\mathrm{R}, \mathrm{H}, \mathrm{E}, \mathrm{Z}, \mathrm{S})\end{array}$ & $01 / 2003-07 / 2003$ & & & & $x$ & & & $x$ & $x$ & $x$ & $x$ & & Nonadherence \\
\hline Outpatient & Resistance to $(\mathrm{R}, \mathrm{H}, \mathrm{Z})$ & 09/2005-09/2007 & & & & $x$ & & & $\mathrm{x}$ & $x$ & $x$ & $x$ & & Nonadherence \\
\hline Outpatient & $\begin{array}{l}\text { Resistance } \\
\text { to }(R, H, Z) ; \\
\text { Susceptibility to } \\
(E, S)\end{array}$ & $11 / 2007-07 / 2008$ & & & & $x$ & & & $x$ & $\mathrm{x}$ & & $\mathrm{x}$ & & Nonadherence \\
\hline Outpatient & $\begin{array}{l}\text { Resistance to } \\
(\mathrm{R}, \mathrm{H}, \mathrm{E}, \mathrm{Z})\end{array}$ & 08/2008-09/2010 & & & & $x$ & & & $x$ & $x$ & $x$ & $\mathrm{x}$ & & Nonadherence \\
\hline Outpatient & $\begin{array}{l}\text { Resistance to } \\
(\mathrm{R}, \mathrm{H}, \mathrm{E}, \mathrm{Z}, \mathrm{S})\end{array}$ & 06/2011-10/2011 & & & & $x$ & & & & $\mathrm{x}$ & & $x$ & & $\begin{array}{c}\text { Referral for } \\
\text { hospitalization } \\
\text { (at } \\
\text { Sanatorinhos, } \\
\text { in the city of } \\
\text { Campos do } \\
\text { Jordão, Brazil) }\end{array}$ \\
\hline Inpatient & $\begin{array}{l}\text { Resistance to } \\
(\mathrm{A}, \mathrm{C}, \mathrm{K}, \mathrm{S}, \mathrm{E}, \mathrm{H}, \mathrm{O}, \mathrm{Z}, \mathrm{R})\end{array}$ & $10 / 2011-03 / 2013$ & & & $x$ & $x$ & & & & $x$ & & $x$ & $x$ & $\begin{array}{l}\text { Disciplinary } \\
\text { discharge }\end{array}$ \\
\hline Inpatient (HNGR) & $\begin{array}{l}\text { Resistance to } \\
\text { (A,C,S,H,O,Z,R); } \\
\text { Susceptibility to (E) }\end{array}$ & $03 / 2013-08 / 2013$ & & & $x$ & $x$ & & & & $\mathrm{x}$ & & & $x$ & Failure \\
\hline \multicolumn{15}{|l|}{ Patient 2} \\
\hline \multirow{2}{*}{$\begin{array}{l}\text { Outpatient } \\
\text { Outpatient }\end{array}$} & & 03/2011-10/2011 & $x$ & $x$ & $x$ & $x$ & & & & & & & & Failure \\
\hline & $\begin{array}{l}\text { Resistance } \\
\text { to }(R, H, Z, O) \text {; } \\
\text { Susceptibility to } \\
(A, K, C p, S, E)\end{array}$ & $03 / 2012-10 / 2013$ & & & & $x$ & & & & $x$ & & $x$ & $x$ & Failure \\
\hline \multicolumn{15}{|l|}{ Patient 3} \\
\hline \multirow{2}{*}{$\begin{array}{l}\text { Outpatient } \\
\text { Outpatient }\end{array}$} & & $01 / 2006-05 / 2006$ & $x$ & $x$ & $x$ & & & & & & & & & Nonadherence \\
\hline & $\begin{array}{l}\text { Resistance to }(\mathrm{R}, \mathrm{H}) \text {; } \\
\text { Susceptibility to } \\
\text { (Z,E,S,Et) }\end{array}$ & $06 / 2006-06 / 2007$ & $x$ & $x$ & $x$ & $x$ & & & & & & & & Nonadherence \\
\hline Outpatient & $\begin{array}{l}\text { Resistance to }(\mathrm{R}, \mathrm{H}) \text {; } \\
\text { Susceptibility to } \\
\text { (Z,E,S,Et) }\end{array}$ & 08/2007-07/2009 & & & $x$ & $x$ & $\mathrm{x}$ & & $x$ & & & & & Cure \\
\hline Outpatient & $\begin{array}{l}\text { Resistance to }(\mathrm{R}, \mathrm{H}) \text {; } \\
\text { Susceptibility to } \\
(\mathrm{Z}, \mathrm{E}, \mathrm{S})\end{array}$ & 09/2009-04/2010 & & & & $x$ & $x$ & & $x$ & $X$ & & & & Failure \\
\hline $\begin{array}{l}\text { Inpatient (at } \\
\text { Sanatorinhos, in } \\
\text { the city of Campos } \\
\text { do Jordão, Brazil) }\end{array}$ & $\begin{array}{l}\text { Resistance } \\
\text { to }(\mathrm{R}, \mathrm{H}, \mathrm{S}) \text {; } \\
\text { Susceptibility to } \\
(\mathrm{Z}, \mathrm{E})\end{array}$ & $04 / 2010-03 / 2012$ & & & & $x$ & & & & $x$ & & $x$ & $x$ & Failure \\
\hline Outpatient & $\begin{array}{l}\text { Resistance } \\
\text { to }(R, H, S) ; \\
\text { Susceptibility to } \\
(Z, E)\end{array}$ & $02 / 2013-02 / 2014$ & & & $x$ & $x$ & & & & $x$ & & $x$ & $x$ & Failure \\
\hline
\end{tabular}

$\mathrm{R}$ : rifampin; H: isoniazid; Z: pyrazinamide; E: ethambutol; S: streptomycin; Et: ethionamide; O: ofloxacin; T: terizidone; C: clofazimine; A: amikacin; L: levofloxacin; K: kanamycin; Cp: capreomycin; and HNGR: Hospital Nestor Goulart Reis. 
Table 3. Drug susceptibility test results, treatment regimen, body weight, erythrocyte sedimentation rate (ESR), C-reactive protein, sputum smear microscopy, and culture for Koch's bacillus over a one-year period for the three patients studied.

\begin{tabular}{|c|c|c|c|c|c|c|c|c|c|}
\hline Patient & $\begin{array}{c}\text { Drug } \\
\text { susceptibility } \\
\text { testing }\end{array}$ & $\begin{array}{c}\text { Treatment } \\
\text { regimen }\end{array}$ & $\begin{array}{c}\text { Treatment } \\
\text { duration }\end{array}$ & Month & $\begin{array}{c}\text { Weight. } \\
\text { kg }\end{array}$ & $\begin{array}{l}\text { ESR. } \\
\mathrm{mm} / \mathrm{h}\end{array}$ & $\begin{array}{l}\text { CRP. } \\
\mathrm{mg} / \mathrm{l}\end{array}$ & Culture & $\begin{array}{c}\text { Sputum } \\
\text { smear } \\
\text { microscopy }\end{array}$ \\
\hline \multirow[t]{9}{*}{1} & \multirow{9}{*}{$\begin{array}{l}\text { Resistance to } \\
(\mathrm{A}, \mathrm{Cp}, \mathrm{K}, \mathrm{S}, \mathrm{E} \\
\mathrm{H}, \mathrm{O}, \mathrm{Z}, \mathrm{R})\end{array}$} & \multirow{9}{*}{$\begin{array}{l}\mathrm{A}(\text { Mon-Fri })+M+ \\
\mathrm{E}+\mathrm{T}+\mathrm{Et}+\mathrm{Lz}+\mathrm{I}+ \\
\mathrm{Clr}+\mathrm{Cl}\end{array}$} & \multirow{9}{*}{$\begin{array}{l}09 / 2013- \\
09 / 2014\end{array}$} & Baseline & 55.00 & 27 & 31.6 & positive & negative \\
\hline & & & & 1 & 54.15 & 22 & 6.7 & positive & negative \\
\hline & & & & 2 & 54.30 & 24 & $<6.0$ & negative & negative \\
\hline & & & & 4 & 54.85 & 12 & $<6.0$ & negative & negative \\
\hline & & & & 5 & 55.60 & 18 & $<6.0$ & negative & negative \\
\hline & & & & 6 & 56.00 & 13 & $<6.0$ & negative & negative \\
\hline & & & & 8 & 58.55 & 15 & $<6.0$ & negative & negative \\
\hline & & & & 10 & 57.45 & 12 & $<6.0$ & negative & negative \\
\hline & & & & 12 & 58.25 & 8 & $<6.0$ & negative & negative \\
\hline \multirow[t]{7}{*}{2} & \multirow{7}{*}{$\begin{array}{l}\text { Resistance to } \\
(\mathrm{A}, \mathrm{Cp}, \mathrm{K}, \mathrm{S}, \mathrm{H}, \mathrm{O} \text {, } \\
\mathrm{Z}, \mathrm{R}) ; \\
\text { Susceptibility } \\
\text { to (E) }\end{array}$} & \multirow{7}{*}{$\begin{array}{l}\mathrm{S}(\text { Mon-Fri)+ } \\
\mathrm{M}+\mathrm{E}+\mathrm{T}+\mathrm{Et}+\mathrm{Lz}+ \\
\mathrm{I}+\mathrm{Clr}+\mathrm{Cl} \text { - }\end{array}$} & \multirow{7}{*}{$\begin{array}{l}11 / 2013- \\
11 / 2014\end{array}$} & Baseline & 59.40 & 66 & 36.4 & positive & negative \\
\hline & & & & 2 & 58.30 & 7 & $<6.0$ & positive & negative \\
\hline & & & & 4 & 60.90 & 9 & $<6.0$ & positive & negative \\
\hline & & & & 6 & 61.95 & 24 & 6.2 & negative & negative \\
\hline & & & & 8 & 62.55 & 13 & $<6.0$ & negative & negative \\
\hline & & & & 10 & 64.15 & 10 & $<6.0$ & negative & negative \\
\hline & & & & 12 & 64.90 & 6 & $<6.0$ & negative & negative \\
\hline \multirow[t]{7}{*}{3} & \multirow{7}{*}{$\begin{array}{l}\text { Resistance to } \\
\text { (A,Cp,K,S,H,O,R); } \\
\text { Susceptibility to } \\
\text { (E.Z) }\end{array}$} & \multirow{7}{*}{$\begin{array}{l}\mathrm{Cp}(\text { Mon-Fri) }+\mathrm{M}+ \\
\mathrm{E}+\mathrm{T}+\mathrm{Et}+\mathrm{Lz}+\mathrm{I}+\mathrm{Cl}+ \\
\mathrm{Clv}+\mathrm{Z}\end{array}$} & \multirow{7}{*}{$\begin{array}{l}03 / 2014- \\
03 / 2015\end{array}$} & Baseline & 36.30 & 89 & 91.0 & positive & positive \\
\hline & & & & 2 & 40.75 & 10 & 59.1 & positive & negative \\
\hline & & & & 4 & 45.60 & 15 & 17.4 & negative & negative \\
\hline & & & & 6 & 46.10 & 20 & 15.7 & negative & negative \\
\hline & & & & 8 & 47.80 & 15 & 16.1 & negative & negative \\
\hline & & & & 10 & 46.90 & 34 & 9.2 & negative & negative \\
\hline & & & & 12 & 46.70 & 11 & 36.0 & negative & negative \\
\hline
\end{tabular}

CRP: C-reactive protein; A: amikacin; Cp: capreomycin; Clr: clarithromycin; Clv: clavulanate/amoxicillin; S: streptomycin; E: etambutol; Et: ethionamide; I: imipenem; H: isoniazid; K: kanamycin; Lz: linezolid; M: moxifloxacin; O: ofloxacin; Z: pyrazinamide; R: rifampin; T: terizidone; and Mon-Fri: from Monday to Friday.

Preadmission treatment regimens and drug susceptibility test results for the three patients (herein identified as patient 1 , patient 2, and patient 3 ) are presented in Table 2, whereas postadmission treatment regimens, drug susceptibility test results, body weight, smear microscopy results, results of culture for Koch's bacillus, erythrocyte sedimentation rate (ESR), and C-reactive protein are presented in Table 3.

Chest X-rays (Figures 1, 2, and 3 for patients 1, 2, and 3 , respectively), as well as laboratory test results at admission and after 1 year of treatment, can be found in the online supplement of the JBP (http:// www.jornaldepneumologia.com.br/detalhe_anexo. asp?id=43)

\section{Patient 1}

A 43-year-old male smoker (with a smoking history of 20 pack-years) presented to our institution. In addition to social drinking, he reported a history of cocaine use (he had not used it since 2011). He was unofficially employed as a car washer. He had previously been treated for tuberculosis but had not adhered to the prescribed treatment regimens. According to the patient, this was due to the fact that he was granted no social security benefit allowances for tuberculosis and had to work during the treatment period. His family income, in Brazilian reals ( $R \$$ ), was 800.00
(US\$ 363.00). He lived in a two-bedroom household with his mother. He was admitted to HNGR on March 18 , 2013. Treatment for XDR-TB was initiated on September 6, 2013.

\section{Patient 2}

A 41-year-old male smoker (with a smoking history of 20 pack-years) presented to our institution. He was a maintenance assistant. He reported a history of alcohol dependence (he had not consumed any alcohol since 2008) but no illicit drug use. He had been on sick leave while on treatment for tuberculosis, having been granted a social security benefit allowance. His family income was $\mathrm{R} \$ 1,400.00$ (US\$ 437.00). He lived in a single room with his wife, a 1-year-old child, and two teenage children. He was admitted to HNGR on October 24, 2013. Treatment for XDR-TB was initiated on November 1, 2013.

\section{Patient 3}

A 25-year-old female smoker (with a smoking history of 5 pack-years) presented to our institution. She was unofficially employed as a clerk in a bakery. She reported social drinking but no illicit drug use. Her salary was R $\$ 25.00$ (US\$327.00). She had previously been treated for tuberculosis but had not adhered to the prescribed treatment regimens. According to the patient, this was due to the fact that she was granted 
no social security benefit allowances for tuberculosis and had to work during the treatment period. She lived in a three-bedroom household with three other people (a 5-year-old daughter, a brother, and her mother) and slept alone in one of the bedrooms. She had received home oxygen therapy in the period between December of 2013 and her admission to HNGR. She was hospitalized on February 10, 2014. Treatment for XDR-TB was initiated on March 10, 2014.

\section{DISCUSSION}

In the present study, we reported three cases of XDR-TB patients who had previously been treated for tuberculosis. The use of a treatment regimen based on the WHO guidelines in association with a new combination of antituberculosis drugs (imipenem and linezolid) resulted in clinical and bacteriological cure, as well as in significant radiological improvement. To our knowledge, our study is the first in Latin America and the second in the world to report the use of imipenem for the treatment of patients with XDR-TB, as well as being the first in the world to report the cases of three XDR-TB patients who were cured with the use of imipenem-linezolid.

At HNGR, treatment is initiated after careful clinical and medication history taking. Smear microscopy is performed at the hospital. Cultures for Koch's bacillus and drug susceptibility testing are performed at the Adolfo Lutz Institute and repeated every two months. Laboratory tests are performed at the São Paulo State University School of Pharmaceutical Sciences and repeated every three months. At admission, chest $\mathrm{X}$-rays and CT scans are taken, the former being repeated every two months. The initial proposal is inpatient treatment for 24 months, depending on the clinical, bacteriological, and laboratory response.

Both MDR-TB and XDR-TB are multifactorial and are caused by one or more of the following: inappropriate treatment regimens, inadequate drug doses, or inadequate treatment duration; mismanagement of antituberculosis drugs, affecting supply and quality; laboratories where resolution rates are low; addition of one or more drugs to a treatment regimen that has failed; treatment discontinuation or irregular medication use; and infection with primary MDR-TB strains. ${ }^{(1)}$

The chest $X$-rays taken at admission revealed serious pulmonary sequelae in patients 1 and 3 , a finding that might be due to the fact that those patients had been treated for tuberculosis several times before, albeit erratically and, consequently, ineffectively. Patient 2 had received a basic treatment regimen under supervision. The fact that the treatment failed might be attributed to primary MDR-TB.

Patients 1 and 2 received treatment with nine different drugs, and patient 3 received treatment with ten drugs, in accordance with the WHO guidelines for the treatment of MDR-TB (Table 1) and XDR-TB, ${ }^{(1)}$ as well as having received drugs that susceptibility test results showed they were sensitive to. Before their hospitalization, our patients had alternately or inconsistently used group
1 drugs, group 2 drugs, group 3 drugs, and group 4 drugs (Table 2). Patient 1 was the only patient who had used a group 5 drug (clofazimine; Table 2). For patients with XDR-TB, there are few drug options to create an acceptable and effective treatment regimen.(3) Our three patients received an injectable (group 2) drug and a next-generation fluoroquinolone (moxifloxacin). Despite relative contraindications in the WHO guidelines, streptomycin was given to patient 2 because the patient had received amikacin under supervision for approximately 20 months before hospital admission and because capreomycin was unavailable at the time. All patients received group 4 drugs (terizidone and ethionamide) and group 5 drugs (imipenem and linezolid). A case-control study showed the efficacy and tolerability of the meropenem-clavulanate/linezolid combination in the treatment of patients with MDR-TB or XDR-TB. ${ }^{(12)}$ A recent study showed the efficacy of ertapenem as an alternative for the treatment (including outpatient treatment) of MDR-TB. ${ }^{(13)}$ In the present study, clavulanate was used as an adjuvant to imipenem/ cilastatin $^{(1)}$ and in combination with amoxicillin, given that clavulanate is not provided separately. Although the effect of clarithromycin on M. tuberculosis is uncertain, clarithromycin was used in all three patients because of its synergistic effect with linezolid. ${ }^{(1,14)}$ According to the WHO guidelines, ${ }^{(1)}$ ethambutol does not have a key role in the treatment of MDR-TB, even in cases of patients who are susceptible to it (e.g., patients 2 and 3 in the present study). Nevertheless, all three patients in the present study received ethambutol. Patient 3 was the only patient who received pyrazinamide, on the basis of susceptibility test results.

After the first year of treatment, the proposed follow-up consisted of maintaining the use of injectable drugs for 18 months and the use of oral drugs for 24 months (Tables 1 and 3). At this writing, patients 1 and 2 had been discharged as cured, whereas patient 2 had had clinical, radiological, and bacteriological improvement. It is of note that none of the patients had adverse drug reactions.

The pharmacological treatment of XDR-TB is costly. The Brazilian government spent approximately $\mathrm{R} \$ 76,000.00$ (US\$30,000) per year on drugs alone for each of the patients included in the present study. A study conducted in South Africa showed that the treatment of one patient with XDR-TB costs US\$26,392, which is four times higher than the treatment of one patient with MDR-TB (US\$ 6,772) and 103 times higher than the treatment of one patient with tuberculosis that is susceptible to the basic treatment regimen (US\$ 257). ${ }^{(4)}$ In addition, drug-resistant tuberculosis results in destruction of the lung parenchyma, which has an impact on patient quality of life and makes it extremely difficult to calculate post-discharge costs for patients and governments.

In conclusion, governments must make every effort to prevent MDR-TB and XDR-TB. In extreme cases, such as those reported here, hospitalization is required in order to ensure an effective treatment for an adequate period of time. 


\section{REFERENCES}

1. World Health Organization. Global tuberculosis report 2014. Geneva: World Health Organization; 2014

2. Falzon D, Gandhi N, Migliori GB, Sotgiu G, Cox HS, Holtz TH, et al. Resistance to fluoroquinolones and second-line injectable drugs: impact on multidrug-resistant TB outcomes. Eur Respir J. 2013;42(1):156-68. http://dx.doi.org/10.1183/09031936.00134712

3. Migliori GB, Sotgiu G, Gandhi NR, Falzon D, DeRiemer K, Centis R, et al. Drug resistance beyond extensively drug-resistant tuberculosis: individual patient data meta-analysis. Eur Respir J. 2013;42(1):16979. http://dx.doi.org/10.1183/09031936.00136312

4. Pooran A, Pieterson E, Davids M, Theron G, Dheda K. What is the cost of diagnosis and management of drug resistant tuberculosis in South Africa? PLoS One. 2013:8(1):e54587. http://dx.doi. org/10.1371/journal.pone.0054587

5. Diel R, Vandeputte J, de Vries G, Stillo J, Wanlin M, Nienhaus A. Costs of tuberculosis disease in the European Union: a systematic analysis and cost calculation. Eur Respir J. 2014;43(2):554-65. http:// dx.doi.org/10.1183/09031936.00079413

6. Jassal M, Bishai WR. Extensively drug-resistant tuberculosis. Lancet Infect Dis. 2009;9(1):19-30. http://dx.doi.org/10.1016/S14733099(08)70260-3

7. Brasil. Ministério da Saúde. Secretaria em Vigilância em Saúde Departamento de Vigilância Epidemiológica. Programa Nacional de Controle da Tuberculose. Nota técnica sobre as mudanças no tratamento da tuberculose no Brasil para adultos e adolescentes Versão 2. Brasília: Ministério da Saúde; 2009

8. Zumla A, Chalaya K, Centis R, D’Ambrosio L, Mwaba P, Bates $M$, et al Tuberculosis treatment and management--an update on treatment regimens, trials, new drugs, and adjunct therapies. Lancet Respir Med. 2015;3(3):220-34. http://dx.doi.org/10.1016/S22132600(15)00063-6

9. Falzon D, Jaramillo E, Schünemann HJ, Arentz M, Bauer M, Bayona $\mathrm{J}$, et al. WHO guidelines for the programmatic management of drugresistant tuberculosis: 2011 update. Eur Respir J. 2011;38(3):516-28. http://dx.doi.org/10.1183/09031936.00073611

10. Franke MF, Appleton SC, Mitnick CD, Furin JJ, Bayona J, Chalco $\mathrm{K}$, et al. Aggressive regimens for multidrug-resistant tuberculosis reduce recurrence. Clin Infect Dis. 2013;56(6):770-6. http://dx.doi. org/10.1093/cid/cis1008

11. Velásquez GE, Becerra MC, Gelmanova IY, Pasechnikov AD, Yedilbayev A, Shin SS, et al. Improving outcomes for multidrugresistant tuberculosis: aggressive regimens prevent treatment failure and death. Clin Infect Dis. 2014;59(1):9-15. http://dx.doi.org/10.1093/ $\mathrm{cid} / \mathrm{ciu} 209$

12. De Lorenzo S, Alffenaar JW, Sotgiu G, Centis R, D'Ambrosio $L$, Tiberi $S$, et al. Efficacy and safety of meropenem-clavulanate added to linezolid-containing regimens in the treatment of MDR-/XDR-TB. Eur Respir J. 2013;41(6):1386-92. http://dx.doi. org/10.1183/09031936.00124312

13. Tiberi S, D’Ambrosio L, De Lorenzo S, Viggiani P, Centis R, Sotgiu G, et al. Ertapenem in the treatment of MDR-TB: first clinical experience. Eur Respir J. 2015 Nov 19. pii: ERJ-01278-2015. [Epub ahead of print]

14. Bolhuis MS, van Altena R, van Soolingen D, de Lange WC, Uges DR, van der Werf TS, et al. Clarithromycin increases linezolid exposure in multidrug-resistant tuberculosis patients. Eur Respir $\mathrm{J}$. 2013;42(6):1614-21. http://dx.doi.org/10.1183/09031936.00001913 